ELORE (ISSN 1456-3010), vol. 19 - 1/2012.

Julkaisija: Suomen Kansantietouden Tutkijain Seura ry.

[http://www.elore.fi/arkisto/1_12/saarikoski.pdf]

Ajankohtaista

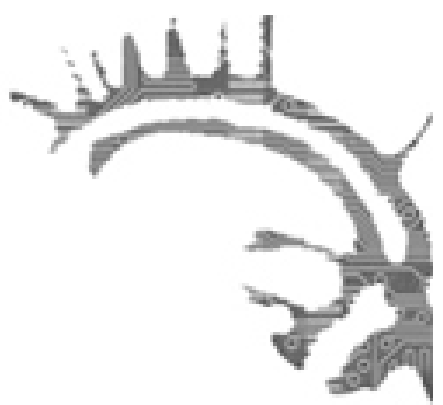

\title{
ESITYSTUTKIMUKSEN VERKOSTO
}

\author{
Helena Saarikoski
}

Esitystutkimus, Performance Studies, on jo maailman yliopistoissa paikkansa lunastanut oppiaine (katso esimerkiksi Tisch Performance Studies). Sen tutkimuskohteeseen kuuluvat niin taide-esitykset estetiikkoineen kuin kulttuuriset arkipäivän esitykset ja arjesta eroavat spektaakkelit ja rituaalit sekä identiteetin aspektien kuten sukupuolen, ikäryhmän, etnisyyden ynnä muiden esittäminen ja esityksellisyys. Yhteistä on fokus esitykseen, tässä ja nyt tapahtuvaan ruumiilliseen vuorovaikutukseen; esityksen toimiminen linssinä, jonka läpi historiaa, yhteisöä ja kulttuuria katsotaan. Esitystutkimuksen metodologiana on usein etnografia, jonka menetelmin haihtuvia esityksiä dokumentoidaan tutkittaviksi ja kuvataan tutkimuksessa.

Esitysnäkökulmaista tutkimusta tehdään Suomessakin paljon ja monella alalla, mutta oppiaine ei ole meillä saavuttanut jalansijaa itsenäisenä tieteenalana. Uuden Esitystutkimuksen verkoston tavoitteena on paikata tätä puutetta luomalla keskustelufoorumi ja yhteistyömuotoja suomalaisille esitystutkijoille.

Folkloristiikassa esitysnäkökulma on ollut paradigmaattisessa asemassa suunnilleen viimeiset kolmekymmentä vuotta (katso esimerkiksi Honko 2000, 13-15). Folkloristiikka onkin yksi tieteidenvälisenä risteysalana syntyneen esitystutkimuksen emotieteistä, kulttuuriantropologian, teatterintutkimuksen, etnomusikologian, kielitieteen ja muiden ohella. Esitysnäkökulma on siinä määrin kirjautunut sisään tieteenalan lausumattomiin premisseihin, että moni folkloristi saattaa tehdä esitystutkimusta tietämättään. Minulle silmiä avaava opetus tästä oli Åbo Akademissa 2004 järjestetty seminaari Pelkkää esitystä? Performatiivisuus kulttuurien tutkimuksessa (katso Immonen [2004]). Monien folkloristien ja uskontotieteilijöiden, muiden muassa Tuija Hovin, Anna Hynnisen ja Lotte Tarkan, kiinnostavien esitelmien joukossa mieleenpainuvin minulle oli sosiologi Elina Oinaksen kertomus, joka vastasi täsmälleen omia kokemuksiani. Kaikki olivat tolkuttaneet hänelle niin paljon, että "sitten käytät tietenkin Butlerin teorioita", että 
Helena Saarikoski: Esitystutkimuksen verkosto

hän oli suorastaan päättänyt olla lukematta koko Butleria - kunnes kerran luettuaan ei voinut olla myöntämättä, että tietenkin käyttää Butlerin teorioita. Itse olin vihdoin ottanut kirjan kauniiseen käteen edellisen vuoden kesällä. Ehkä Turun seminaarista jäi kytemään ajatus, että esityksestä ja performatiivisuudesta olisi syytä tehdä systemaattisemmin ja suuremmallakin joukolla selkoa.

Esitystutkimuksen verkosto perustettiin vuoden 2011 alussa Helsingissä eri tiedeja taidekorkeakouluissa toimivien tutkijoiden voimin. Kiinnekohtana toimi Suomen ainoa professuuri, jonka alassa esitystutkimuksen käsite on mainittu, esitystaiteen ja -teorian professuuri Teatterikorkeakoulussa ja sen nykyinen haltija Annette Arlander. Perustavaan kokoukseen helmikuun alussa saapui kymmenen tutkijaa, joiden edustamien tieteenalojen skaala ulottui pelitutkimuksesta ja teatterin-, tanssin- ja liikkeentutkimuksesta musiikintutkimukseen, taidehistoriaan ja folkloristiikkaan.

\section{INNOLLA LIIKKEELLE}

Verkosto on aloittanut toimintansa kahdella tutkimuspäivällä, jotka on järjestetty Tieteiden talolla Helsingissä. Ensimmäinen esitystutkimuksen päivä toukokuussa 2011 järjestettiin yhteistyössä Suomen Etnomusikologisen Seuran kanssa. Otsikolla "Minun esitykseni" kutsuttiin kaikkien alojen tutkijoita kertomaan omasta esitysnäkemyksestään ja esityksen paikasta omassa tutkimuksessaan. Huikeat 21 halukasta puhujaa mahdutettiin yhteen intensiiviseen päivään. Folkloristit ja yleisemmin kulttuuristen esitysten tutkijat olivat uutterina paikalla puolustamassa tonttiamme taide-esitysten tutkimuksen ja taiteellisen tutkimuksen rinnalla - toki myös oppimassa toisilta.

Toinen esitystutkimuksen päivä järjestettiin jo puolen vuoden kuluttua, tällä kertaa yhteistyössä Kulttuurintutkimuksen seuran kanssa, otsikolla Arjen performatiivisuus. Puhumaan otettiin nyt vain yhdeksän tutkijaa ja jätettiin tiukan esitelmäputken sijasta runsaasti aikaa keskustelulle. Kaikki aika tuli käytettyä; paljon jäi vielä puhuttavaa yli.

Kaksi ensimmäistä tutkimuspäivää ovat keränneet yhteensä kolmekymmentä tieteellistä ja taiteellista tutkijaa eri aloilta esittelemään meneillään olevia tutkimuksiaan. Verkoston kokoavana tiedotuskanavana toimivaan blogiin on koottu kummankin tutkimuspäivän esitelmien tiivistelmät (Esitystutkimus > artikkelit"Minun esitykseni”" toteutunut ohjelma ja tiivistelmät; Arjen performatiivisuus 18.11.2011 - tiivistelmät).

\section{SIJAN ETSIMISTÄ TIEDEYHTEISÖSSÄ}

Esitystutkimuksen verkosto on toistaiseksi pysytellyt sitoutumattomana ja epämuodollisena organisaatioltaan. Käytännössä tapahtumia on järjestänyt kolmen naisen työryhmä, professori Annette Arlander Teatterikorkeakoulusta, tutkijatohtori Taina Riikonen Sibelius-Akatemian DocMus-yksiköstä ja minä kulttuurientutkimuksen ja folkloristiikan edustajana. Emme ole halunneet liittyä minkään olemassa olevan tieteellisen seuran alaverkostoksi, vaikka se varmasti helpottaisi muun muassa tapahtu- 
majärjestelyjä ja tiedotusta. Esitystutkimus kuuluu yhtä hyvin kulttuurintutkimukseen, etnomusikologiaan, teatterintutkimukseen kuin kansantietouden tutkimukseen, yhtä hyvin kulttuurisen kuin taiteellisen tekemisen ja tapahtumisen tutkimukseen. Aidosti monitieteisen ja tieteidenvälisen yhteistyön muotojen hakeminen vakiintuneessa tieteenalaorganisaatiossa ei ole helppoa. Mutta parhaimmillaan uudenlainen yhteistyö aukoo aivan uusia ajatusten uria vanhojen urautumien tilalle.

Esitystutkimuksen verkosto on vasta alussa ja avoin kaikenlaisille aloitteille. Lähitulevaisuuden haasteena on varmastikin sellaisten perustavien tutkimuskysymysten muotoilu, jotka yhdistävät kulttuuristen ja taiteellisten esitysten tutkijoita yli tieteenalarajojen, ja sellaisten yhteistyömuotojen luominen, joissa näitä kysymyksiä voidaan hedelmällisesti työstää yhdessä.

\section{KirJallisuUs}

Esitystutkimus. Esitystutkimuksen verkoston blogi. [Online] < http://esitystutkimus. wordpress.com/ > [25.2.2012.].

HONKO, LAURI 2000: Thick Corpus and Organic Variation: an Introduction. Honko, Lauri (toim.), Thick Corpus, Organic Variation and Textuality in Oral Tradition. Studia Fennica Folkloristica 7. Helsinki: Finnish Literature Society.

IMMONEN, VISA [2004]: Pelk.kää esitystä? Performatiivisuus kulttuurien tutkimuksessa -seminaari. Turku 2.4.2004. [Online] < http://www.helsinki.fi/hilma/tiedotus/ esitysta.htm $>$ [25.2.2012.].

Tisch Performance Studies. The Tisch School of Arts, Department of Performance Studies. [Online] < http://performance.tisch.nyu.edu/object/what_is_perf.html > [25.2.2012.].

Folkloristiikan ja naistutkimuksen dosentti, filosofian tohtori Helena Saarikoski on vapaa tutkija ja Kulttuuriosuuskunta Partuunan toimitusjohtaja. Hän tutkii parhaillaan suomalaisia lavatansseja Suomen Kulttuurirahaston stipendiaattina. 